\title{
Living without buffers-illustrating climate vulnerability in the Lake Victoria basin
}

\author{
Sara Gabrielsson • Sara Brogaard • \\ Anne Jerneck
}

Received: 19 March 2012/ Accepted: 26 September 2012/Published online: 20 October 2012

(C) The Author(s) 2012. This article is published with open access at Springerlink.com

\begin{abstract}
Exposure, sensitivity and adaptive capacity are essential, albeit theoretically vague, components of climate vulnerability. This has triggered debate surrounding how these factors can be translated into, and understood in, an empirical context subject to present and future harm. In this article, which draws on extensive fieldwork in the Lake Victoria Basin of Kenya and Tanzania, we illustrate how exposure, sensitivity and adaptive capacity play out in the context of climate vulnerability and discuss how they interact in situ. Using a mixed methods approach including survey data, rainfall data and a suite of participatory methods, such as focus groups and interactive mapping of seasonal calendars, we identify how climate-induced stressors affect smallholder farmers' well-being and natural resources. Drawing on the seasonal calendar as a heuristic, and climate vulnerability terminology, we illustrate when, where and how these climate-induced stressors converge to constrain farmers' livelihoods. Our analysis indicates that farmers in the basin face a highly uncertain future with discernible, but differentiated, adaptation deficits due to recurring, and potentially worsening, patterns of hardship.
\end{abstract}

Keywords Climate vulnerability - Exposure ·

Sensitivity · Differential adaptive capacity .

Smallholder farmers · Lake Victoria Basin

Handled by Will Steffen, Australian National University, Australia.

S. Gabrielsson $(\bowtie) \cdot S$. Brogaard · A. Jerneck

Centre for Sustainability Studies, Lund University (LUCSUS),

PO Box 170, 22100 Lund, Sweden

e-mail: sara.gabrielsson@lucsus.lu.se

\section{Introduction}

The realization that climate change is posing tangible threats to the sustainability of humanity has given rise to new scientific inquiries, such as the emerging research field of sustainability science (SS). SS aims to understand the conditions of human-environment interactions and find ways to meet the needs of society while at the same time ensuring that the planet's life support systems are sustained (Turner et al. 2003; Clark 2007). Conceptualizing vulnerability is a central element within both SS and the climate change discourse owing to the significance of questions such as: who and what is vulnerable to certain climate stressors, where may these be located, how may various societal or natural conditions amplify this vulnerability, and what can be done to respond to and reduce these vulnerabilities? The appeal of vulnerability as a concept lies in its inclusive nature, whereby humans and the natural environment are seen as intimately coupled and differentially exposed, differentially sensitive, and differentially adaptable to threats (Polsky et al. 2007). Studying this is difficult, arguably perhaps impossible, because it demands a thorough investigation of every biophysical, social, cultural and cognitive aspect of human-environment interactions (ibid). Accordingly, research focusing on coupled human-environment systems calls for theoretical expertise and methods from several research fields, such as risk- and disaster-management, political ecology, sustainable livelihoods frameworks and resilience research (Ingram et al. 2010). This realization has resulted in many frameworks that attempt to understand vulnerability (Wisner and Luce 1993; Watts and Bohle 1993; Ribot et al. 1996; Kasperson and Kasperson 2001; Brooks 2003; Cutter et al. 2003; Turner et al. 2003; Schröter et al. 2005; Adger 2006; Füssel and Klein 2006; Polsky et al. 2007, Scoones and Thompson 
2009; Ionescu et al. 2009; Hinkel 2011; Preston et al. 2011) even if vulnerability itself, like sustainability, can neither be observed nor measured directly, but rather must be deduced (Hinkel 2011). Some scholars (Patt et al. 2009), argue that these theoretical developments have lured scientists into the trap of simplifying the complexity and uncertainty of a specific vulnerability system to such an extent that it may no longer be helpful for our overall understanding of what vulnerability entails.

Because of this 'epistemological trap' there is a need for in-depth, place-based assessments, especially in places like the Lake Victoria Basin (LVB) in East Africa, where imminent vulnerabilities are present (Fuggle 2002; United Nations Environment Program 2006; Olago et al. 2007; Odada et al. 2009) and where such integrative investigations are missing. But there may be many financial and temporal constraints on the performance of such an inclusive vulnerability assessment ranging over a vast number of communities, including the knowledge and participation of affected stakeholders. Consequently, this calls for a more generalizable and easily transferable methodology for vulnerability assessments that can be applied in settings where such constraints are severe, including the LVB.

Inspired by Schröter et al. (2005), we constructed and applied a modified version of their assessment approach for analyzing the climate vulnerability of smallholder farmer livelihoods in the LVB. Our objective is an empirical analysis of the convergence of climate induced stressors and of how such dynamics turn into recurring periods of hardship detrimental to local communities in terms of low food security and low well-being. Drawing on a range of mainly qualitative data, and following a multi-scalar strategy that combines village data with regional district level data, as recommended by other scholars (see Morton 2007; Preston et al. 2011), we assess 'the factors that determine the potential for harm from exogenous threats as well as the endogenous adaptive capacity' (Preston et al. 2011: p 183). To that end we have tried to downscale global climate change into the local context in which it is experienced. From that position we map local vulnerability through participatory processes. By emphasizing the temporal aspects of climate vulnerability and by examining the differential adaptive capacities of farmers to buffer themselves against such vulnerabilities, we show the importance of place-based vulnerability mapping and analysis for informing viable climate adaptation and development policies.

\section{Conceptualizing climate vulnerability}

Vulnerability is a compound of three partly overlapping elements: exposure, sensitivity and adaptive capacity (McCarthy et al. 2001; Yohe and Tol 2002; Adger 2003;
Smit and Pilifosova 2003) (Fig. 1). Exposure is defined as the degree to which a system experiences environmental or socio-economic stress (Adger 2006). To exemplify: how may rainfall increase in a particular period or how may droughts extend over time? Sensitivity refers to the extent to which a system is modified or affected by such stress. For example, how many more people are at risk of catching malaria when rainfall increases? (Adger 2006: p. 270). Adaptive capacity refers to the ability to cope with and adapt to these changes. For example, what are people's capacities to reduce the risk of contracting malaria?

Clearly, these elements are highly inter-related and there are broad social, economic, political and ecological conditions that affect all three elements to varying degrees. Complexity is thus a key feature of vulnerability in this dynamic system of interlinked components in continuous flux. Uncertainty is also a critical factor affecting the system, since we are studying not only present vulnerabilities but also future potential impacts, where our knowledge is limited because data are based on anticipated changes, rather than actual. This temporal dilemma can be tackled by using the actual context-specific and process-sensitive empirical material already available to us and analyzing it through theoretically informed reasoning, i.e., what is known as 'retroduction' (Ragin 2011).

There are (at least) two distinctive camps in vulnerability research. The first, referred to as outcome vulnerability (O`Brien et al. 2007), has grown out of various risk-hazard and impact frameworks (see Füssel and Klein 2006). It focuses on the impacts of climate change in terms of measurable units on various sectors in society. The second, contextual vulnerability, proceeds from the constructivist literature on entitlements and livelihoods frameworks (see

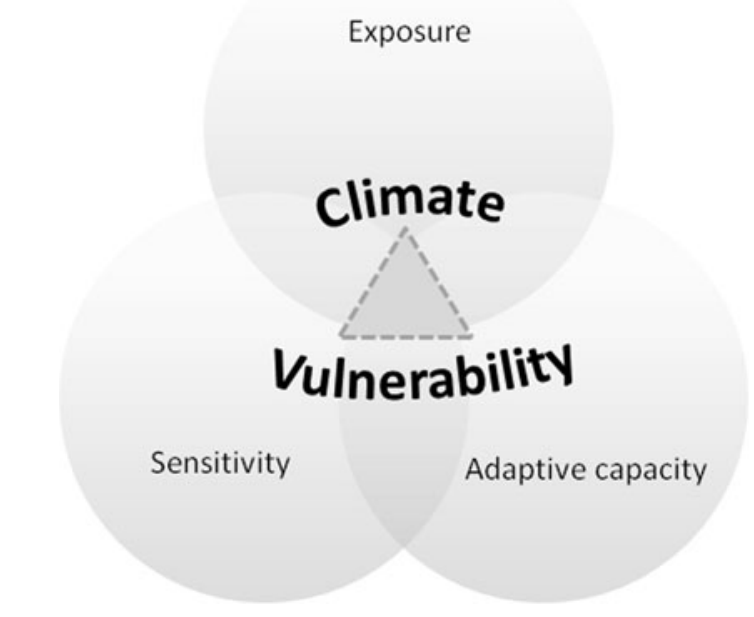

Fig. 1 The three overlapping elements of climate vulnerability (source: Gabrielsson 2012) 
Dreze and Sen 1991; Sen 1999; Watts and Bohle 1993; Ribot et al. 1996; Adger 2006). It focuses on the variation and dynamics of vulnerability within and between social groups in society, thus emphasizing aspects of inequality and distribution. Our conceptualization of climate vulnerability draws upon both of these frameworks in an effort to relate exposure, sensitivity and adaptive capacity to each other in an integrated manner, as called for by Hinkel (2011). This is demonstrated in our interactive work on seasonal calendars (see section below on Seasonal pattern of hardship and coping), which we see as a novelty and thus a contribution to the vulnerability debate in climate change research.

\section{Analytical framework and integration of field methods}

Drawing on Schröter et al. (2005) and adapted to our study context, five criteria guide our climate vulnerability analysis. First, we include a multitude of different types of data, thus necessitating and allowing for interdisciplinary research and the inclusion of non-scientists. Second, and following Cutter et al. (2003), we understand vulnerability as place-based and context-specific, hence the need to pay attention to the nesting of scales. Third, we recognize multiple socio-ecological stressors and feed-back mechanisms, which we attempt to capture in the seasonal calendars. Fourth, we allow for differential adaptive capacities and thus identify the barriers and constraints within the human-environment system that make it possible for some to adapt but others not. Fifth, we follow the principle that empirical material must be both historical and contemporary while also providing a prospective potential. Hence, our data covers statistics, conceptual modelling and oral histories that enable identification of historical patterns and future predictions. Besides laying the foundation for our analytical framework, these criteria influenced our research strategy and guided the choice and design of our field methods.

The article draws on research and data from repeated fieldwork in 2007-2011. The study is predominately qualitative, based on various types of interviews and focus groups, participatory exercises and a multi-stakeholder workshop but also includes certain crucial quantitative information such as a household survey and rainfall data (Table 1). Four smallholder farming communities (Onjiko, Thurdibuoro, Kunsugu and Kisumwa) located in the coastal low-lying provinces of Nyanza, Kenya and Mara, Tanzania (Fig. 2) participated in the study.

Local stakeholders were involved in our research at several junctures to give us the opportunity to test, evaluate and verify initial empirical findings. This also enhanced the iterative process by allowing empirical data to be revised and revisited throughout the research process. Initially, this was done through interviews with stakeholders, specifically farmers themselves, but also other informants working locally such as health care practitioners, representatives from non-governmental organizations (NGOs) and politicians, i.e., location chiefs or ward executive officers. Subsequently, through the organization and execution of a multi-stakeholder workshop, it served as a first step to raise awareness and open up a critical dialogue about climate adaptation. Importantly, it also served to increase collaboration between high-end stakeholders themselves as well as between them and local farmers.

\section{Contextualizing climate vulnerability in the LVB}

The most fundamental connection between natural systems and human well-being in the LVB appears to be smallholders' heavy dependence on biophysical assets for their livelihoods. Barrett (2008) argues that when the key state variables of two systems are shared then strong interdependence follows automatically. Emerging questions relate to the nature of these interrelationships and the balancing or reinforcement of feedbacks within and between systems. In the communities we studied, people rely on rain-fed mixed agriculture based on labor-intensive small-scale farming and livestock rearing. Drawing on the 'Baseline household survey' (Gabrielsson 2007), we see that farmers grow a wide range of crops, such as maize (staple in Onjiko and Thurdiburo) and cassava (staple in Kisumwa and Kunsugu), cow peas, millet, rice, sunflowers, various vegetables and, in some instances, cash crops like cotton or water melons, farmed on small plots, ranging between 0.5 and 3 acres on the Kenyan side and 0.5 and 6 acres in Tanzania. The majority also keep poultry, goats, cattle and dairy cows in varying small numbers. Fuel-wood is the primary energy source and water for domestic and productive needs comes primarily from nearby rivers, streams and/or artificial ponds. Farmers also engage in a number of off-farm activities to obtain cash.

Despite tremendous advances in agricultural science and technology, climate and weather are the most important variables in food production (Rosenzweig et al. 2001). Since rain-fed agriculture is the mainstay of peoples' livelihoods in the study region, any change in the pattern of rainfall contributes to a destabilization of the food system, in terms of influencing production, use and/or access to food with potentially negative feedbacks on livelihoods (Misselhorn 2004; Ingram et al. 2010). Grasping the dynamics of rainfall in the LVB is therefore fundamental to our understanding of how it induces changes in the coupled human-environment system. 
Table 1 Fieldwork data collection and participatory activities in Kenya and Tanzania

\begin{tabular}{|c|c|c|c|c|c|}
\hline When & How & Who & Where (Kenya) & $\begin{array}{l}\text { Where } \\
\text { (Tanzania) }\end{array}$ & What \\
\hline $\begin{array}{l}\text { September } \\
2006\end{array}$ & $\begin{array}{l}\text { Semi-structured } \\
\text { interviews }\end{array}$ & $\begin{array}{l}\text { Key informants working on } \\
\text { vulnerability related issues }\end{array}$ & $\begin{array}{l}\text { University of } \\
\text { Nairobi, } \\
\text { UNEP, SIDA } \\
\text { CARE, ILRI, } \\
\text { ICRAF, ACTS }\end{array}$ & $\begin{array}{l}\text { University } \\
\text { of Dar Es } \\
\text { Salaam, } \\
\text { ViAFP, } \\
\text { CEEST }\end{array}$ & $\begin{array}{l}\text { Key problems and challenges of } \\
\text { small scale agriculture in the LVB, } \\
\text { predicted climate change and } \\
\text { impacts, national and local } \\
\text { adaptation policies and strategies }\end{array}$ \\
\hline $\begin{array}{l}\text { September- } \\
\text { October } \\
2007\end{array}$ & $\begin{array}{l}\text { Household } \\
\text { questionnaires }\end{array}$ & $\begin{array}{l}\text { HH randomly selected based on two } \\
\text { criteria: exposure to drought/flood } \\
\text { and engagement in agroforestry }\end{array}$ & $\begin{array}{l}100 \mathrm{HH} \text { in two } \\
\text { locations; } \\
\text { Onjiko and } \\
\text { Thurdibuoro, }\end{array}$ & $\begin{array}{l}100 \mathrm{HH} \text { in } \\
\text { two } \\
\text { wards; } \\
\text { Kisumwa } \\
\text { and } \\
\text { Kunsugu }\end{array}$ & $\begin{array}{l}\text { Demographics, livelihood activities } \\
\text { and assets, agroforestry practices, } \\
\text { climate information and impacts, } \\
\text { coping mechanisms, assistance }\end{array}$ \\
\hline $\begin{array}{l}\text { October- } \\
\text { November } \\
2008\end{array}$ & $\begin{array}{l}\text { Informal open } \\
\text { ended } \\
\text { discussions }\end{array}$ & $\begin{array}{l}\text { Extension officers at Vi- } \\
\text { Agroforestry }\end{array}$ & $\begin{array}{l}\text { One working in } \\
\text { Nyando } \\
\text { district }\end{array}$ & $\begin{array}{l}\text { One } \\
\text { working } \\
\text { in } \\
\text { Musoma } \\
\text { district }\end{array}$ & $\begin{array}{l}\text { Outlining features of the place. } \\
\text { Identifying resource use. Locating } \\
\text { droughts and floods. Discussing } \\
\text { cultural traditions and practices, } \\
\text { and the moral economy. Tracing } \\
\text { land rights and land tenure }\end{array}$ \\
\hline $\begin{array}{l}\text { October- } \\
\text { November } \\
2008\end{array}$ & $\begin{array}{l}\text { Historical } \\
\text { transect walks }\end{array}$ & $\begin{array}{l}\text { Location chiefs in selected locations/ } \\
\text { wards }\end{array}$ & $\begin{array}{l}\text { One each in } \\
\text { Onjiko, } \\
\text { Thurdibuoro } \\
(n=2)\end{array}$ & $\begin{array}{l}\text { One each in } \\
\text { Kisumwa } \\
\text { and } \\
\text { Kunsugu } \\
(n=2)\end{array}$ & $\begin{array}{l}\text { Comparing changes in resource use, } \\
\text { livelihood activities and landscape } \\
\text { over time. Identifying availability } \\
\text { and access to local and outside } \\
\text { networks including formal/ } \\
\text { informal organizations }\end{array}$ \\
\hline $\begin{array}{l}\text { October- } \\
\text { November } \\
2008\end{array}$ & $\begin{array}{l}\text { Episodic } \\
\text { interviews }\end{array}$ & $\begin{array}{l}\text { Elderly farmers selected from } \\
\text { among respondents in } \mathrm{HH} \text { survey }\end{array}$ & $\begin{array}{l}\text { Onjiko }(n=3) \\
\text { Thurdibuoro } \\
(n=3)\end{array}$ & $\begin{array}{l}\text { Kisumwa } \\
(n=3) \\
\text { Kunsugu } \\
(n=6)\end{array}$ & $\begin{array}{l}\text { Comparing life today with the } \\
\text { situation } 10 \text { years ago, } 20 \text { years } \\
\text { ago, and their childhood regarding: } \\
\text { climate, income sources, health } \\
\text { agricultural production and } \\
\text { marketing, social networks, access } \\
\text { to natural resources, labor } \\
\text { responsibilities, coping strategies }\end{array}$ \\
\hline $\begin{array}{l}\text { October- } \\
\text { November } \\
2008\end{array}$ & Focus groups & $\begin{array}{l}\text { Two groups with women; two } \\
\text { groups with men and women } \\
\text { ( } n=8 \text { per group) }\end{array}$ & $\begin{array}{l}\text { One each in } \\
\text { Onjiko and } \\
\text { Thurdibuoro }\end{array}$ & $\begin{array}{l}\text { One each } \\
\text { in, } \\
\text { Kunsugu } \\
\text { and } \\
\text { Kisumwa }\end{array}$ & $\begin{array}{l}\text { Identifying perceptions on climate } \\
\text { induced changes. Perceived } \\
\text { impacts on livelihoods and range } \\
\text { of responses both short and long } \\
\text { term }\end{array}$ \\
\hline 2008, 2009 & $\begin{array}{l}\text { Precipitation } \\
\text { data }\end{array}$ & Where local data was available & $\begin{array}{l}\text { Kisumu Airport, } \\
\text { Ahero, Kibos } \\
\text { and Awasi } \\
\text { stations }\end{array}$ & $\begin{array}{l}\text { Musoma } \\
\text { Airport } \\
\text { and } \\
\text { Tarime } \\
\text { station }\end{array}$ & $\begin{array}{l}\text { Monthly and daily rainfall data } \\
\text { between } 1951 \text { and } 2008\end{array}$ \\
\hline $\begin{array}{l}\text { September } \\
2009\end{array}$ & $\begin{array}{l}\text { Mapping of } \\
\text { seasonal } \\
\text { calendars }\end{array}$ & $\begin{array}{l}\text { Four local groups, two with women } \\
\text { only ( } n=10-30 \text { /group) }\end{array}$ & $\begin{array}{l}\text { Thurdibuoro and } \\
\text { Onjiko }\end{array}$ & $\begin{array}{l}\text { Kisumwa } \\
\text { and } \\
\text { Kunsugu }\end{array}$ & $\begin{array}{l}\text { Mapping of climate, health, income, } \\
\text { expenditure, food production and } \\
\text { consumption/year }\end{array}$ \\
\hline $\begin{array}{c}\text { January } \\
2010\end{array}$ & $\begin{array}{l}\text { Multi- } \\
\text { stakeholder } \\
\text { workshop } \\
\text { (2 days) }\end{array}$ & $\begin{array}{l}\text { LVB stakeholders: KARI, KEFRI, } \\
\text { LVDC KEMRI,U of Nairobi, } \\
\text { Kenya Seed, Vi-AFP, Red Cross, } \\
\text { Equity Bank, LVEMP, Maseno } \\
\text { Uni, ILRI, KMFRI, SIDA, Local } \\
\text { farmers from both Kenya and } \\
\text { Tanzania }\end{array}$ & $\begin{array}{l}\text { Held in Kisumu, } \\
\text { Kenya } \\
(n=65)\end{array}$ & & $\begin{array}{l}\text { Identifying impacts of climate } \\
\text { variability and change on local } \\
\text { communities. Identifying current } \\
\text { coping and adaptation strategies, } \\
\text { alternative future pathways, } \\
\text { synergies and future needs for } \\
\text { collaboration between existing } \\
\text { actors }\end{array}$ \\
\hline $\begin{array}{c}\text { January } \\
2011\end{array}$ & $\begin{array}{l}\text { Focus group } \\
\text { and individual } \\
\text { interviews }\end{array}$ & Widows, two groups ( $n=7 /$ grp) & Onjiko & & $\begin{array}{l}\text { Challenges and opportunities of } \\
\text { being a widow in a small holder } \\
\text { context }\end{array}$ \\
\hline
\end{tabular}

$H H$ Households, $L V B$ Lake Victoria Basin 
Fig. 2 Map of Lake Victoria Basin (LVB) with marked study sites (source: International Lake Environment Committee 2005)

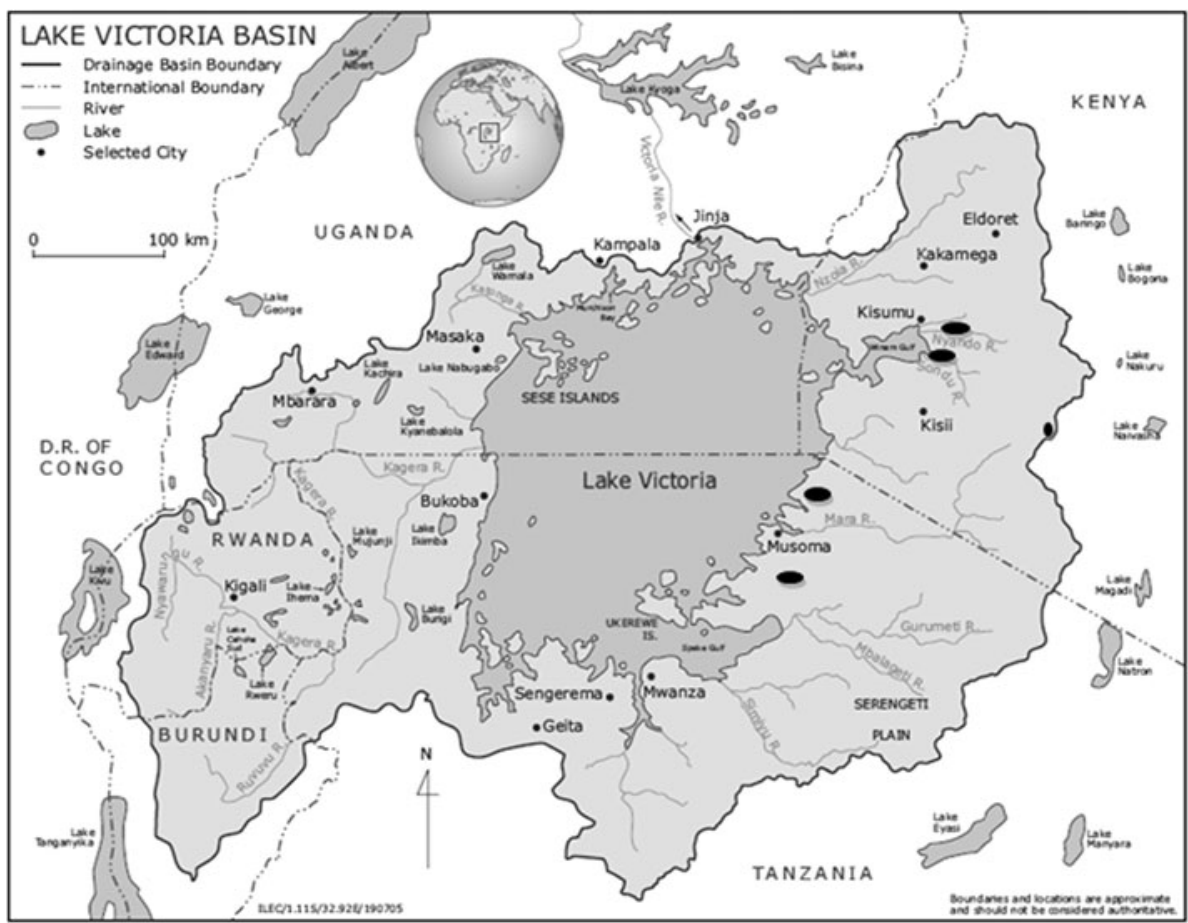

\section{Locating exposures}

The bi-modal rainfall pattern constitutes a primary parameter around which agricultural and herding activities are organized in the East African region (Smucker and Wisner 2008). This pattern is associated with interlinked, complex, and as yet not fully understood climate drivers such as the movements of the inter-tropical convergence zone, the large scale (African) monsoonal winds, El-Niňo Southern Oscillation (ENSO) phenomena, the quasi-biennial oscillation, the meso-scale circulations and extratropical weather systems (Kizza et al. 2009). According to both elders and contemporary farmers, the long rainy season (masika) normally spans March-May, while October signals the onset of the short rainy season (vuri) that generally lasts until mid-December (field data, 2007-2010). During some periods, inter-annual rainfall variability is extreme, leading to heavy downpours and/or prolonged dry periods, often linked to the ENSO (Ogallo 1997; McHugh 2006). Despite the generally complex climate parameters involved in analyzing rainfall dynamics in the LVB, recent regional climate studies have successfully identified an overall increasing trend indicating a rise in rainfall, specifically during the short rainy season (Kizza et al. 2009; Thornton et al. 2010). Our own analysis based on time series on monthly rainfall from two stations and used as a proxy for the study sites in Kenya and Tanzania, although not always uniform across the two, indicate a similar pattern, specifically during the short rainy season. Figure 3 illustrates this pattern (Fig. 3a, b) based on precipitation data from Kisumu and Musoma meteorological stations from 1951/1959 to 2007/2008. The high rainfall during vuri in 1961 shows a deviation from this pattern and signifies an exceptional El-Niňo year (United Nations Environment Program 2006).

In addition, we see a deviating pattern in the long rainy season compared to the past, whereby rainfall is increasing slightly in January but decreasing in February and April (Fig. 3c-h). It should be noted that, because monthly data alone may be insufficient in identifying the rather subtle divide between variability and trends, 'trends' in our data are only significant in some cases due to high rainfall variability in the area; hence we use the term 'pattern' here rather than trend.

Although changes in the rainfall pattern at the study sites seem small, such changes may be critical to farmers because of the way they dictate agricultural performance (United Nations Environment Program 2006) as indicated by farmers' own experiences:

We cannot predict when it will rain anymore. Now we don't have a fixed time when we plant, we have to read the weather to know when to plant. Because of the change it has made life much more difficult, so it is all dependent on trial and error (Tom, 29 October 2008, Kenya).

The rainfall was better in the past compared to today. Now the rains are not enough for our needs. The rains are much more unreliable today (Taabu, 12 November 2008, Tanzania). 
a

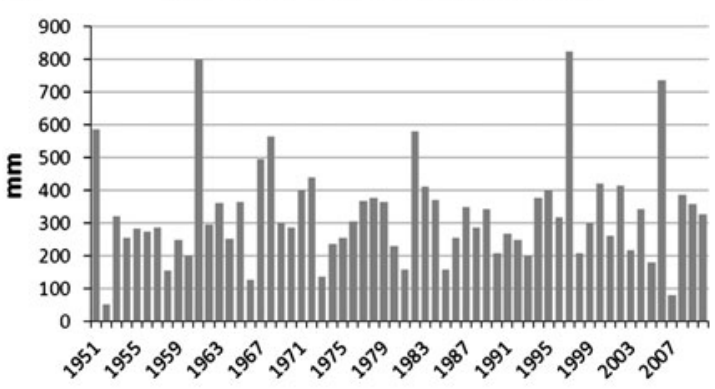

C

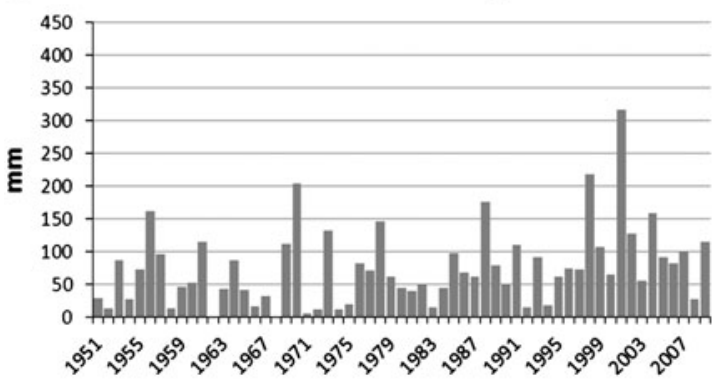

e

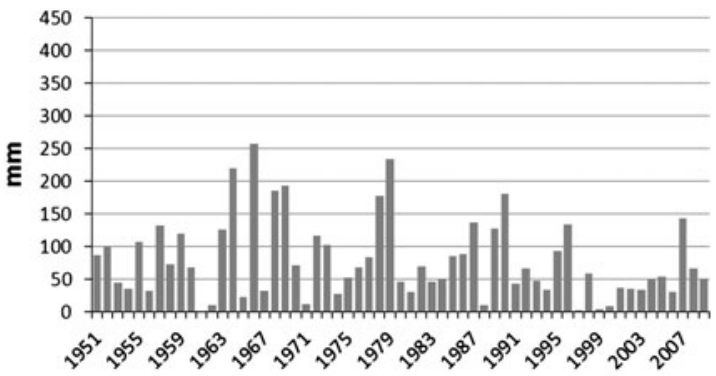

g

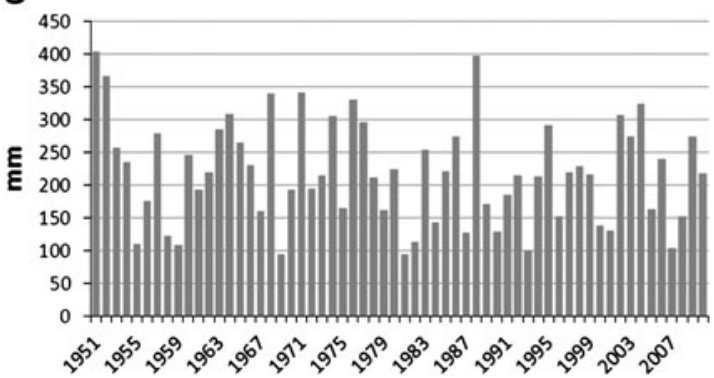

Fig. 3 a, b Rainfall pattern for the short rainy season (OctoberDecember) at Kisumu (1951-2007) and Musoma (1959-2007) meteorological station (source: Kenya Meteorological Agency and Tanzania Meteorological Services, 2008). c-h Rainfall pattern for the

It rains more heavily now when it rains than before. It is now destructive. Before when it rained it was not as heavy and then it was useful for the farm rather than now when it cannot be utilized by the soil (Wilfrieda, 27 October 2008, Kenya). b Musoma short rains Oct-Dec

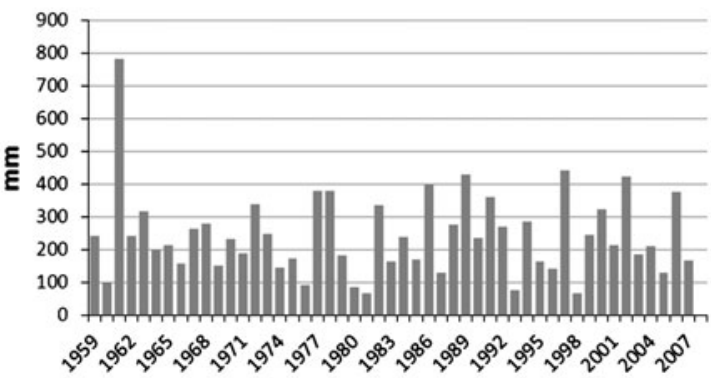

d

Musoma January

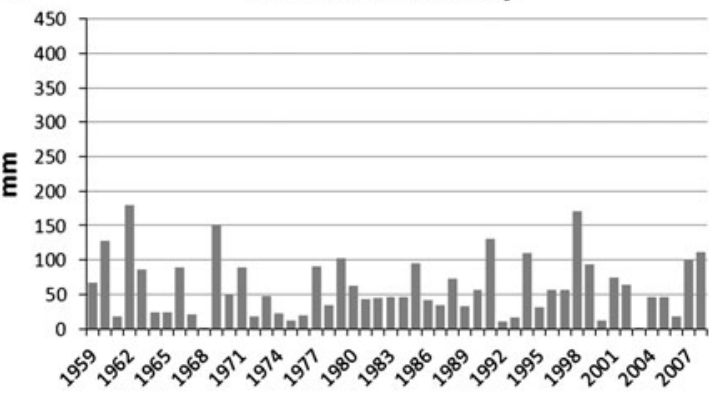

f

Musoma February

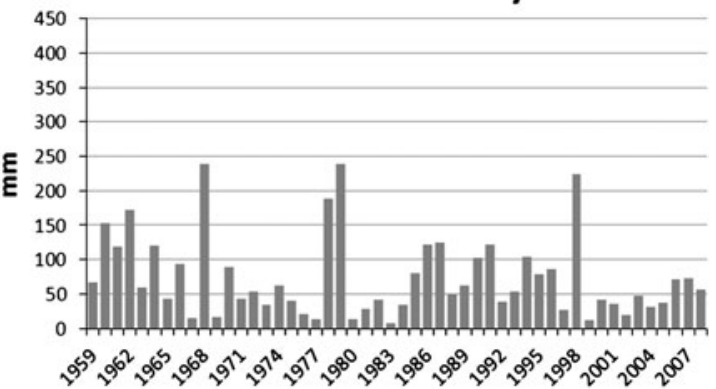

h

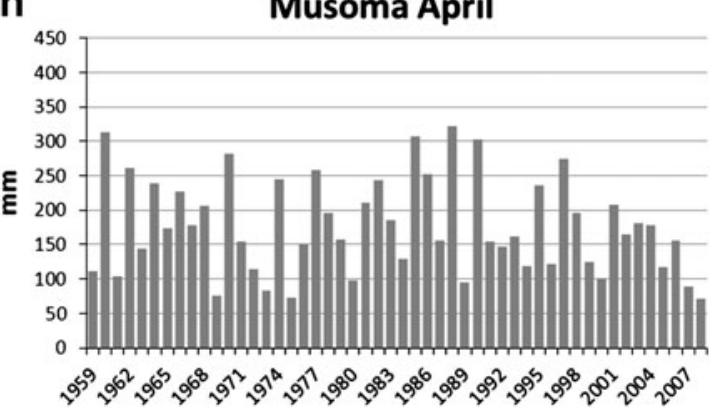

months of January, February and April at Kisumu (1951-2008) and Musoma (1959-2007) meteorological station (source: Kenya Meteorological Agency and Tanzania Meteorological Services, 2008)

It is the timing of the planting of the crop that is key. In the past everyone would plant their crops in February because they were targeting the long rains in April. But now in April there is very little rain so it 
means that they do not get enough harvests (Joseph, 23 October 2008, Kenya).

In the past it rained a lot and the season was longer and we could harvest as planned (Kiega, 17 November 2008, Tanzania).

In the past the rain followed the season but now it does not... [Today] rain ends before the growth of the seedlings is finished. Now we are just guessing when we should plant (Paul, interview 14 November 2008, Tanzania).

People do not know when to plant anymore. They may plant and then crops are destroyed and then they have to plant again (Rose, 23 October 2008, Kenya).

The quotations above illustrate the way farmers interpret the delicate balance between rainfall and plant growth in determining the success or failure of crop production. Moreover, they direct attention to findings made by Barron et al. (2003) that indicate that rainfall analysis alone is often unsatisfactory for identifying agro-meteorological conditions and changes. Hence, by using only a meteorological definition of drought to interpret impacts on agricultural production we would potentially overlook farmers' broader perception of what is known as 'agricultural drought' (i.e., soil water drought), which occurs when there is lack of soil water in the root zone to sustain crops and pasture between rainfalls (Slegers and Stroosnijder 2008). While agricultural drought is not as drastic as meteorological drought, it is still a partial cause of loss in crop productivity and may also reduce viable grazing land, spread new pests and subsequently change livestock production strategies (Smucker and Wisner 2008). This complex bio-geo-physical interaction seems to reinforce farmers' sense of drought and/or intense rainfall (United Nations Environment Program 2006; Slegers and Stroosnijder 2008). Since soils in the study areas have low fertility, poor texture and are used intensively (Odada et al. 2009; Swallow et al. 2009), we argue that a combination of these factors and livelihood outcomes helps to explain why farmers' perceive rainfall as unpredictable or unreliable because it is simply no longer favourable to their food production needs. A comprehensive understanding of the way farmers interpret changes in rainfall dynamics is therefore important as an indicator of exposure to climate vulnerability.

Locating sensitivities and differential adaptive capacities

Historically, favourable rainfall combined with an abundance of fertile soils made the LVB an attractive region to inhabit (United Nations Environment Program 2006). But
Table 2 Featured sensitivities in the four communities

\begin{tabular}{|c|c|c|c|c|}
\hline & $\begin{array}{l}\text { Onjiko, } \\
\text { KE } \\
(n=50)\end{array}$ & $\begin{array}{l}\text { Thurdiburo, } \\
\text { KE } \\
(n=50)\end{array}$ & $\begin{array}{l}\text { Kunsugu, } \\
\mathrm{TZ} \\
(n=50)\end{array}$ & $\begin{array}{l}\text { Kisumwa, } \\
\text { TZ } \\
(n=50)\end{array}$ \\
\hline \multicolumn{5}{|c|}{$\begin{array}{l}\text { Estimated land } \\
\text { size }\left(\text { acres/ } / \mathrm{HH}^{\mathrm{a}}\right)\end{array}$} \\
\hline$>1$ acre & 20 & 13 & 5 & 2 \\
\hline $1-3$ acres & 25 & 26 & 13 & 31 \\
\hline \multicolumn{5}{|c|}{$\begin{array}{l}\text { Animal protein } \\
\text { intake (days/ } \\
\text { week }^{\mathrm{a}} \text { ) }\end{array}$} \\
\hline 1-3 days & 35 & 31 & 15 & 30 \\
\hline Every day & 2 & 6 & 18 & 3 \\
\hline \multicolumn{5}{|c|}{$\begin{array}{r}\text { Food sufficiency } \\
\left(\text { months/year }{ }^{\mathrm{a}}\right)\end{array}$} \\
\hline $1-3$ & 19 & 10 & 14 & 6 \\
\hline $10-12$ & 6 & 5 & 17 & 19 \\
\hline
\end{tabular}

${ }^{a}$ Response options in the original survey were more than those given here; subsequently, the total number of $\mathrm{HH}$ in each featured category is less than the total of $50 \mathrm{HH}$ sampled from each community. Source: baseline survey of a total of $600 \mathrm{HH}$ conducted in September-October 2007

this historical suitability for farming has also led to a rapid growth in population density, from 1 million in 1960 to more than 30 million today and expected to reach 53 million by 2025 (Wandiga 2006). This population pressure has resulted in a fragmentation of agricultural land; for instance individual farming plots along the Kenyan side of the basin have decreased from 2.75 ha per person in 1975 to 0.5 ha in 2004 (United Nations Environment Program 2006). Our survey reveals that farmers in our study areas have even smaller plots, some even less than three acres per household (see Table 2).

Demographic changes and the reduction in land holdings have necessitated an intensification of agricultural production throughout the region, including also in Onjiko and Thurdibouro, where shifting cultivation of diversified crops has been replaced by predominately sedentary monocropping. In Kunsugu and Kisumwa, formerly areas with heavy livestock-rearing, the number of livestock per family has dropped significantly and reliance on food crops is now higher than in the past (field data 2008). These shifts have also contributed to the spread of invasive weeds and a further loss of crop productivity (Smucker and Wisner 2008). To maintain food production, farmers have responded to these negative feedbacks by increasing labor activities, such as weeding, during intense periods of the growing season. But it is not easy for everyone to obtain the labor needed, as Jane explains:

Manpower is lacking now. Only parts of the farmland are tended in the way I want and thus yields are not as high as they could be (Jane, 29 October 2008, Kenya). 
Table 3 Climate-related diseases afflicting households during 2006

\begin{tabular}{lllll}
\hline & $\begin{array}{l}\text { Onjiko, } \\
\text { KE } \\
(n=50)\end{array}$ & $\begin{array}{l}\text { Thurdiburo, } \\
\text { KE }\end{array}$ & $\begin{array}{l}\text { Kunsugu, } \\
\mathrm{TZ} \\
(n=50)\end{array}$ & $\begin{array}{l}\text { Kisumwa, } \\
\mathrm{TZ} \\
(n=50)\end{array}$ \\
\hline $\begin{array}{l}\text { Malaria } \\
\begin{array}{c}\text { Dengue } \\
\text { fever }\end{array}\end{array}$ & 41 & 43 & 49 & 48 \\
$\begin{array}{c}\text { Diarrhoea } \\
\text { Diarhe }\end{array}$ & 3 & 0 & 25 & 23 \\
\hline
\end{tabular}

Source: Baseline survey of a total of $600 \mathrm{HH}$ conducted in September-October 2007

Moreover, strenuous labor requires well-nourished and healthy individuals. Our study indicates that the majority of people are neither. In fact, the population is sensitive to several vector- and water-borne diseases, many with clear linkages to climatic conditions, including, but not limited to, malaria, typhoid, dengue fever, schistosomiasis, cholera and trachoma (Focus groups 2009).

[In the past] we could fetch water from the river and drink it. There were no diseases like dysentery, cholera and malaria like today (Wilfrieda, 27 October 2008, Kenya).

Being the worst and most common disease, malaria affects nearly every family in any given year (Table 3), thereby making it endemic and the leading cause of mortality and morbidity in both children and adults in the basin (Wandiga et al. 2006). Farmers also indicate a rise in the incidence of the disease and its presence on a year round basis:

Nowadays malaria is a bigger problem, making people sick more often (Neema, 17 November 2008,

Tanzania)

According to Githeko (2009), this rise may be linked to increasing rainfall variability, which contributes to the spread of mosquito habitats over time and space. Cholera is also endemic to the LVB but the frequency and severity of episodes have increased in the last 20 years, explained in part by climate changes (Wandiga 2006). People most at risk are those who drink untreated water from Lake Victoria or its tributaries, have poor sanitation and share food with already sick individuals, especially at funeral feasts (Olago et al. 2007). Since most farmers in our study areas rely on these freshwater sources for their productive and/or domestic water needs and regularly attend funerals they are highly sensitive to contamination. This imminence to periodic climate-associated ill-health is compounded by the high prevalence of HIV/AIDS in the basin, estimated to be as high as $15 \%$ of the population on the Kenyan side and even higher among widowed and divorced women (Okuro 2008). Widowhood is a social condition that invariably, and for various reasons, increases sensitivity to other diseases, according to several widows in our study. Yet, by

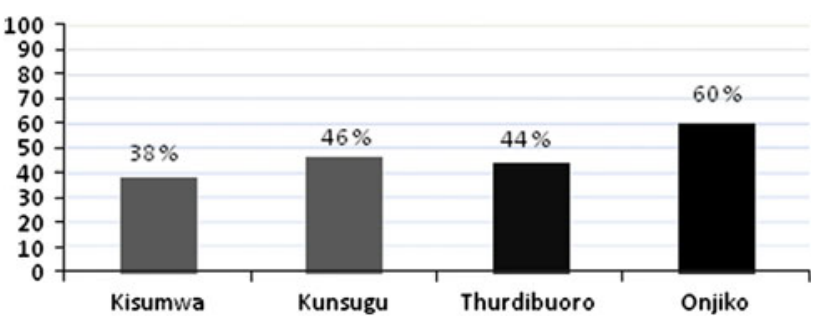

Fig. 4 Percentage of households without males between 19 and 35 years of age (source: baseline survey of a total of 200 households, September-October 2007)

some it is also seen as a window of opportunity for working together with other widows to achieve social change (Gabrielsson 2012).

Sensitivity to diseases is also linked to a non-varied diet, rich in carbohydrates (maize and cassava) and low in animal proteins (Table 2), which leads to micro-nutrient deficiencies and subsequently a weaker immune system that enables and prolongs sickness (Kennedy et al. 2003). The health of individuals could therefore be considered the most important asset controlled by farmers, in fact a capability (Sen 1999). But due to the extent and endemic nature of the climate-associated diseases in LVB, avoiding and preventing disease is difficult and this initiates yet another negative feedback loop, which erodes basic bodily functions even further, and limits the capacity to work, learn and subsist (Dasgupta 1997; Paavola 2008). In our study areas there is, however, a significant lack of males in the age bracket 19-35 years (Fig. 4), indicating that the HIV/AIDS pandemic, along with other fatal diseases mentioned above, has already had palpable effects in transforming the composition of families in the region. This is a highly important deficit considering the lost opportunities and potential that younger working-age males can provide in terms of muscle power and/or non-farm incomes.

Able-bodiedness (Cleaver 2005), land and livestock, as we have seen, are thus important livelihood assets in this rural context of smallholder farming. These livelihood assets or entitlements/capabilities (Sen 1999) and/or forms of capital (Scoones 1998; Bebbington 1999), divided generally into natural, financial, physical, human, social, cultural and institutional assets, are identified as the adaptive capacities that allow for livelihood survival and adaptation. Accordingly, the more capital and capabilities people command in the right mix and with the right strategies, the greater their capacity to buffer themselves against external shocks (Moser 1998). Nevertheless, capacity to adapt is neither collective nor static but rather an individual and dynamic process, influenced by cultural norms and the enabling/disabling environment of the community, which furthermore is reflective of the available resources and political economy of the region (Ribot et al. 1996; Yohe and Tol 2002; Smit and Pilifosova 2003). In our study 
Fig. 5 Demography in Kunsugu and Thurdibuoro by age group and sex (source: baseline survey of a total of 200 households, September-October 2007)
KUNSUGU

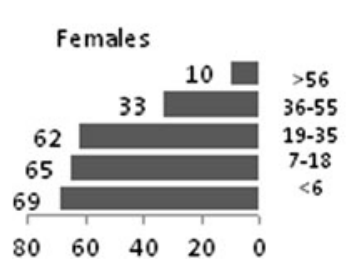

THURDIBUORO

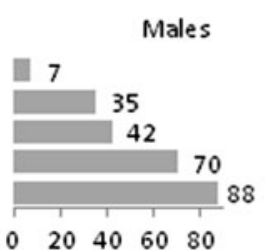

Females

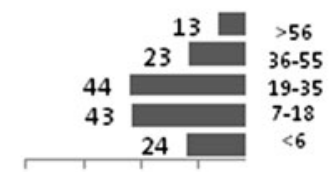

$\begin{array}{lllll}80 & 60 & 40 & 20 & 0\end{array}$
Males

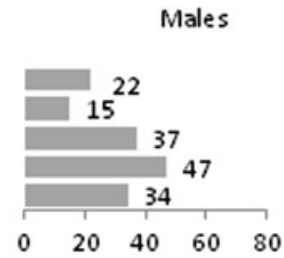

setting, as elsewhere in rural areas of Sub-Saharan Africa, farmers' rights and responsibilities are highly gendered, thus adaptive capacities are also gender differentiated (Masika 2002; Denton 2002; Food and Agricultural Organization 2006; Demetriades and Esplen 2008). As a result, the adaptive capacities of the so-called dependants that women are deemed responsible to care for (the elderly, the young and the sick) are also differentiated since they too have limited abilities to obtain and exploit key livelihood assets controlled by adult men (Enarson 2000; Gabrielsson 2012). Our survey shows that in Tanzania women generally have more dependants (elderly and young children) to care for compared to in Kenya. Figure 5 illustrates this difference by comparing the population pyramids for Kunsugu and Thurdibuoro, respectively.

In Kunsugu the number of children under the age of six is 157, compared to only 58 in Thurdiburo. Whereas a high number of children in the past signified wealth and high status (Gunga 2009), today many farmers, especially women, wish to have fewer children because of the increasing expense associated with them, in terms of health care, food, school fees, supplies and uniforms (Focus groups 2008 and 2011). According to data from focus groups, a common way of 'balancing' the household budget in all four communities during times of hardship is, therefore, to withdraw children from school or in extreme cases, as exemplified in Kunsugu, to marry off young females (between 12 and 15) to reduce expenditures and mouths to feed (field data, 2008).

The great majority of farmers have identified the problems of the lack of manpower, dwindling food production and declining soil fertility but only a limited number of them have taken action. By employing their primary asset, themselves, and joining hands some farmers are able to plan, save and work collectively to intensify food production. The benefits of these collective action groups have proven numerous, including more time and resources available for long-term diversification, preventative activities, experimentation and resource conservation (Andersson 2012). However, the scaling up of this seemingly viable adaptation strategy may be hampered by the fact that the existence of and access to such formalized groups are currently divided along gender and ethnic lines, marginalizing some and excluding others (field data 2008-2011).
Seasonal pattern of hardship and coping

While it is interesting to identify the elements of climate vulnerability in isolation, their integrated effects are probably more significant, albeit less widely discussed. Accordingly, and inspired by Hutchinson's (1998) diagram showing available household strategies in times of famine, we asked farmers to describe their annual pattern of livelihood activities and stressors including climate (rainfall and temperatures), health (disease affliction), food consumption (degree of insecurity) and expenses (on basic needs including food). Similarly, we mapped their agricultural and animal husbandry activities and the annual distribution of on- and off-farm incomes and then combined the participatory exercise results from all four communities into a generalized seasonal calendar. While individual factors, such as the incidence of diseases and food costs differed between communities, a similar pattern of hardship could be identified in all study locations for a typical year. The core of the calendars thus reflects farmers' general consensus of a 'conventional' bimodal rainy season, irrespective of the observed and perceived changes in rainfall dynamics in recent years.

The 'wheel of hardship', seen in Fig. 6, is a summary of these findings indicating that livelihood conditions and activities differ considerably throughout the year, rendering farmer households more or less exposed and sensitive to climate-induced stressors and with more or less capacity to cope with impacts. Interestingly, comparisons of data from the four sites show that conditions differ more throughout the year than between locations. When integrating the results two key periods of severe livelihood hardship can be identified; January-March and October-November. Within these, January and February are the worst hardship months because climate exposure coincides with increased sensitivity to diseases and limited buffers, due chiefly to lack of food and income opportunities imposed by high expenditures for food, school fees, medical needs, renting of grazing land and hiring of agricultural labor. Similar conditions apply to the months of October and November but are usually less severe since households still have staple crops left from the previous harvest and can also sell newly harvested vegetables. 


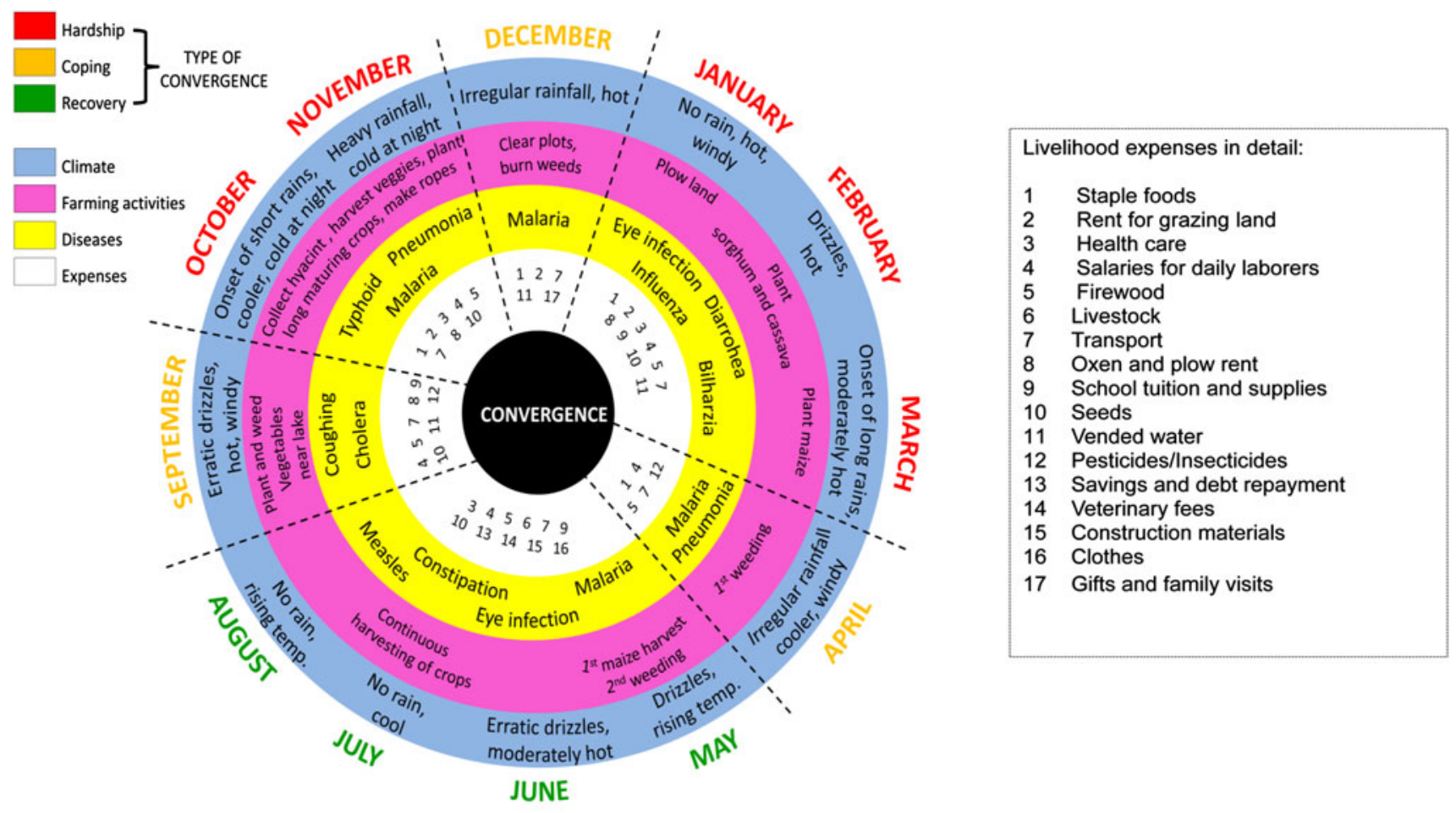

Fig. 6 'Wheel of hardship'-a generalized seasonal calendar illustrating livelihood conditions and stress based on participatory exercises with smallholder farmers from four communities in the LVB

Fortunately, periods of recovery also exist, the main occurring between May and August. From data we learn that crops have matured and fish are abundant in lakes and streams, which means that caloric (and protein) needs are met while crops can be sold and possibly even stored. Grazing land is also lush and green, so there is no problem of extra costs for animal feed. Subsequently, families who can afford them make major household investments, including purchases of livestock, house-building materials, clothes, agricultural tools and seeds. Medical check-ups and veterinary visits are also common. Organized farmers, mostly women, also repay debts and make significant contributions into micro loan and saving schemes, which they can later use during hardship periods. The buffering potential is, however, dependent on crop performance and local market sale prices, which in turn are dictated by rainfall, setting limits for the potentials of the harvest in this rain-fed agriculture.

During the remaining months of the year (September, December and April) households are again under pressure because food supplies are declining rapidly, while they must simultaneously spend much time on weeding and clearing land. But since rainfall is less intense and disease burdens are lower throughout these months, households do cope because livelihood expenses are lower and food supplies are not yet exhausted. During hardship periods, on the other hand, these buffers are not available and hunger looms, which forces many households to drain their liquid assets in an effort to relieve livelihood stress. Figure 7 illustrates the order of these employed mechanisms; interestingly, they form a similar and recognizable pattern, which was formerly followed mainly during severe droughts and famines (see Hutchinson 1998).

Today, however, farmers employ these coping mechanisms on a more regular and recurrent basis (Focus groups 2008-2009). This, we argue, signifies that a substantial shift in the degree of livelihood stress is currently underway among rural smallholders in the LVB, away from occasional and sudden hardship periods, caused by temporary climate extremes (meteorological droughts and floods), and towards livelihoods driven and characterized by recurrent and persistent agricultural drought and subsequent chronic livelihood stress. Similar changes have also been observed in other rural smallholder settings. For example, Smucker and Wisner's (2008) study in Tharaka, Kenya, demonstrates that the variety of coping mechanisms employed by farmers has diminished considerably compared to 20 years ago. In a study from northern Tanzania, Traerup and Mertz (2011) show how contemporary farmers increasingly rely on similar and sometimes competitive strategies, with exacerbated livelihood stress as a result. Similarly, in Kisumwa, diversification through specializing in beer making and charcoal production is a key coping strategy among women as a means to increase household 
Fig. 7 Generalized pattern of coping with climate variability and change. The figure is based on focus groups with smallholder farmers from four communities in the LVB. Adapted from Hutchinson (1998) and modified by the authors

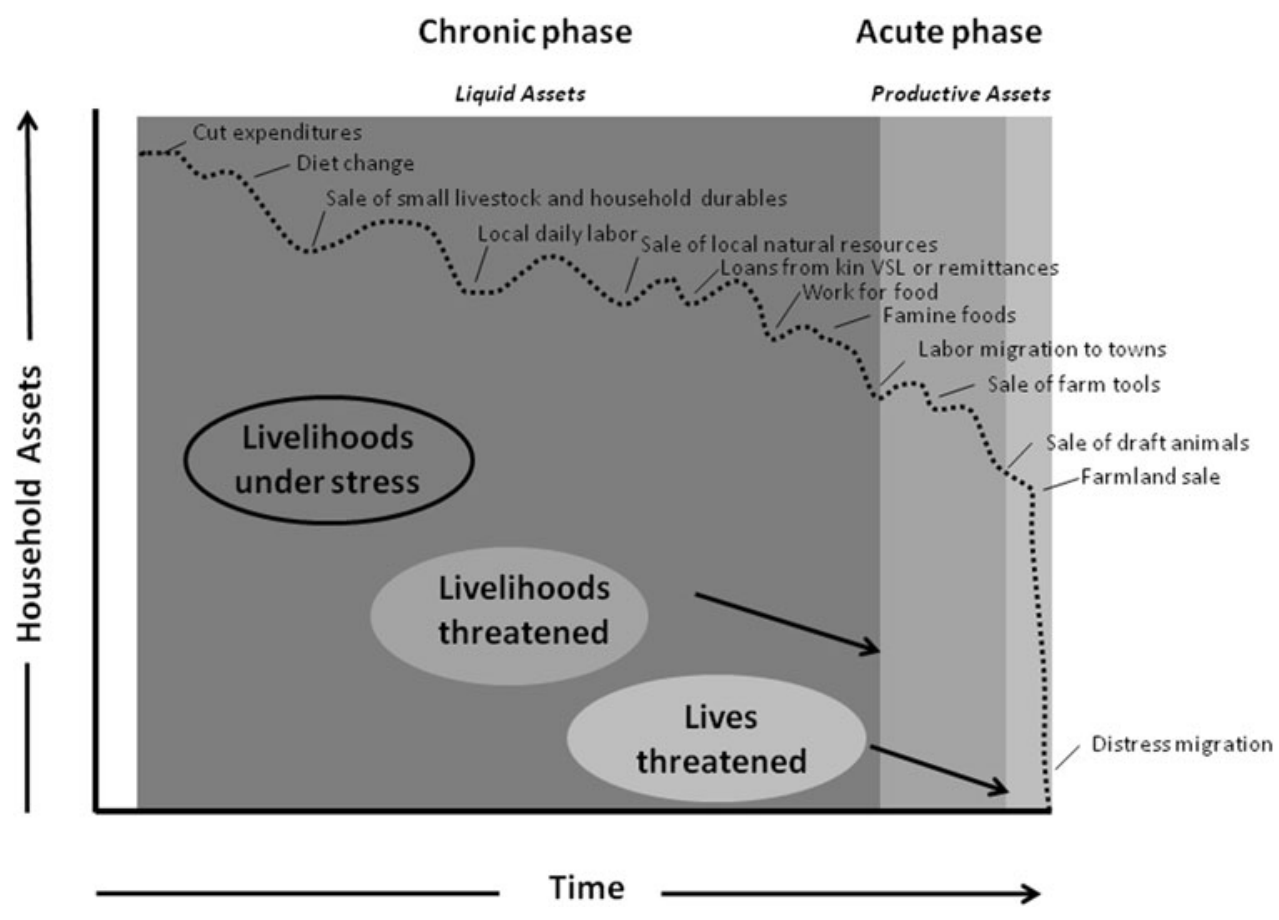

incomes during hardship periods, while in Thurdibuoro and Onjiko diversification, through sales of ropes, baskets, dried fish and tomatoes, is common. A difficulty with such widespread reliance on a similar coping mechanism in one and the same community, in combination with a narrowing of overall strategies, is a decline in available natural resources and the saturation of home-made products in the local market place (field data 2008-2009). Not only does this reduce everyone's income potential and margins, but also the viability of the coping strategy as such. A lack of other alternatives may, however, explain this reliance on diversification. As land becomes infertile and fragmented, the expansion of agriculture has become unfeasible in the LVB. Similarly, migration is no longer as attractive to farmers as it used to be because the competition for unskilled work has increased between ruralites and the urban poor (field data, 2008-2010) as also noted by other scholars in similar sub-Saharan settings (Bryceson 2002; Cleaver 2005; Ellis and Freeman 2005). Intensification is still a possibility, but in the short term it demands an increase in the supply of labor and in the long term greater agricultural expertise to make management sustainable (Pretty et al. 2011), both of which are currently in short supply in the communities we have studied (Andersson 2012). Hence. agricultural diversification is likely to continue to play a key role in the future management of chronic livelihood stress. But whether or not it is a sustainable adaptation strategy and viable for everyone, is still uncertain, given the current reliance on similar strategies and the differential adaptive capacities to implement those adaptations. Moreover, there may be limits to how much one can diversify due to the (often) increased labor burden, limited market integration and lack of transport infrastructure (Eriksen et al. 2005; Miles 2007).

Three lessons with significance for our understanding of climate vulnerability can be drawn from this analysis. Firstly, smallholder livelihoods are becoming increasingly separated from their natural surroundings, because the majority of natural resources needed for basic livelihood survival are either no longer available or no longer accessible to them, other than in the cash-based market economy. This means that small-holding farmers today have mainly become consumers in, rather than producers for, the local market. This is illustrated by the following quotation from one of the farmers interviewed:

Life is harder now, everything needs money. In the past people were exchanging food with each other, food was available at all times (Paul, 14 November 2008, Tanzania).

Consequently, due to recurring, yet variable, shortages of home grown food in all four communities throughout the year (see Table 2), farmers are not only dependent on purchasing food but also need to buy fuel wood, seeds and water at times as well as renting grazing land in order to survive-resources that in the past were produced and/or collected directly from natural surroundings. This monetarization requires families to ensure a steady flow of cash into the household. Particularly important is securing money to buy staple foods, since that consumes the biggest 
share of budgets in the households studied (field data, 2008, 2009). But supply and demand for staple food crops is inelastic (there are no alternative substitutes and the imperative to fulfill basic caloric needs is great) so even a small change in actual or expected supply results in a large change in market prices (Minot 2010). Volatile food prices thus put buyers as well as sellers at the mercy of the market, which makes budget planning difficult, both in predicting future costs but also in anticipating potential profits, as explained below by the ward location chief in Kisumwa.

Prices of the produce are increasing. Of course farmers are getting more for their produce but because they are producing less they are actually also getting less money for it today than in the past. A sadolin (4 kg) of maize cost 500 Tsh 3 years ago and now 1900 Tsh. Cassava was 300 Tsh 3 years ago and 1200 Tsh today (Kisumwa ward location chief, 12 November 2008, Tanzania).

The geographical location of farmers in our areas, far distant from major food producing areas, capital markets and international ports, together with their own fluctuating food production, makes farmers here particularly exposed to both temporal and spatial price volatility (Minot 2010). And as net buyers of food during hardship periods, such volatility has adverse affects, forcing many to limit their meals and/or change their diets to 'famine foods' and/or to sell household assets, including valuable livestock, at a loss (cf. Hutchinson 1998).

The second lesson relates to the existence of numerous 'costs' exacted by the recurring incidence of climate-associated diseases on farmer livelihoods. Besides personal trauma and tragedy, diseases have direct impacts on households through the health care costs incurred or funeral expenses. Indirectly, ill-health may thus lead to loss of anticipated non-farm incomes and added costs of hiring agricultural labor when manpower is reduced or lost. Moreover it also adds to women's labor burdens, as carers for the sick (Gabrielsson 2012). In an area where labor power can arguably be considered a key limiting factor for agricultural intensification, the implications of ill-health are thus far reaching, not only as regards individual livelihood security but perhaps more importantly, as regards the sustainable development of the region as a whole.

The third lesson relates to the uncertainty of coping with hardship in the future. As the wheel of hardship illustrates, there is today a delicate balance between coping, hardship and recovery periods. Currently most farmers have some adaptive capacities that enable them to respond to climate induced stressors, albeit at a cost, and with no evidence of achieving reductions in current climate vulnerability. But the insights into the narrowing of coping strategies, coupled with the observed and experienced changes in rainfall dynamics, draw our attention to the impending difficulties and uncertainties of maintaining this status quo in the future. As a result, even subtle disturbance in the wheel of hardship may cause farmers to slide into greater climate vulnerability (Eriksen et al. 2005).

\section{Concluding discussion and policy implications}

Using an integrated mode of inquiry we have explored and synthesized the three essential, yet theoretically vague, components of climate vulnerability by applying them in a rural farming context in the LVB. Through a range of methods we have thus contributed an empirically grounded and theoretically informed understanding of climate vulnerability. With our seasonal calendars, explicitly building on our field data and design, we are able to study the temporal interactions between nature and society, thereby considering climatic, agronomic and disease dynamics in a place-based setting, as suggested by Thompson (2009). From this we show that time and timing are significant for understanding exposure, sensitivity and adaptive capacities in any attempt to contextualize climate vulnerability. Not only does this exercise generate insights into how these stressors are interrelated, i.e., how they feed into and off each other by contributing to different sensitivities at different times of the year, depending on the type of exposure, it also illustrates that when exposure, sensitivity and limited adaptive capacity converge in time, climate vulnerabilities are greater because of destructive reinforcing feedbacks on the human-environment system. In addition, we show that farmers engage in continuous, yet reactive and autonomous adaptation to climate vulnerability by relying on past experiences of dealing with climate extremes, despite their waning viability in times of increasing climate uncertainty. Current differential adaptive capacities between households and communities indicate a deficit in adaptation potential among smallholder farmers in the LVB, which makes life especially troublesome and the future highly uncertain. In all this, age and gender are pronounced aspects of the capacity of a person, a household or a community to cope with climate-induced impacts, not to mention increasing the adaptive capacities to reduce climate vulnerability.

The wheel of hardship underscores how households rely on a steady flow of cash, food and (healthy) labor power to manage converging aspects of exposure and sensitivities. Historically, farmers have often managed this through increased diversification, which is also seen as a strategy emphasized and promoted by the World Bank (2008). However, our study illustrates that livelihood diversification at household levels is becoming increasingly undermined as a livelihood strategy and that the alternatives, in terms of 
migration and extension of agriculture, now offer only limited opportunities. The only other feasible adaptation strategy for the LVB is therefore to intensify agricultural production. But, as previously mentioned, this hinges not only on peoples' ability to pool labor but also on increased knowledge about how to farm more sustainably in times of global environmental change (Pretty et al. 2011). To enable farmers to do this clearly requires governmental action and financial investment. However, for the 2011/2012 fiscal year governmental spending on the agricultural sector in both Kenya and Tanzania was low, $3.53 \%$ in Kenya, down from $4.7 \%$ in 2009/2010 and $7.7 \%$ in Tanzania, up from $6.4 \%$ in 2008/2009 (Ngombalu 2011: pp. 6-8), despite the fact that the majority of the latter's citizens are involved in farming (International Fund for Agricultural Development 2011)

More importantly, both countries' national adaptation responses [Tanzania National Adaptation Plan of Action (United Republic of Tanzania 2007) 52 pp.; Kenya National Climate Change Response Strategy (Government of Kenya 2010) 120 pp.] acknowledge that recent climate extremes as well as anticipated changes in climate dynamics in the future, will hit the agricultural sector the hardest. Furthermore, they emphasize the importance of guaranteeing food security to enable economic development. Yet, none of the proposed strategies to increase adaptive capacities within the agricultural sector involves or even mentions the role of gender inequality, the fragmentation of land or the limited labor compared with the labor that agricultural intensification would require. The budget proposal in Kenya's strategy further reveals that only $4.5 \%$ of the total 236 billion Kenyan shillings has been allocated for agriculture; $1.1 \%$ for gender, children and social development; and $0.5 \%$ for public health. One could therefore argue that the proposed adaptation policies to cope with and reduce the vulnerability to climate variability and change are contradictory, since only a fraction of the proposed budget and no specific programmes reflect priorities to increase the livelihood security of those affected most disproportionately, such as female headed families with high disease burdens and many children (Table 4). As Devereux and Edwards (2004: p. 28) so poignantly puts it; "the extent to which climate change is taken seriously and is effectively addressed depends primarily on political will". In regard to the national responses to the predicaments of smallholders in the LVB such political will seems to be lacking.

Clearly, our study findings indicate that reducing climate vulnerability among smallholders in the LVB has to involve a multitude of policy responses by various stakeholders, including but not limited to: increasing adaptations to reduce sensitivities by, for example, investing in water and sanitation, adopting drought and flood resistant crops and engaging in sustainable land management practices, such as integrated pest management, agro-forestry, soil conservation and livestock management, as well as enhancing the ability to cope with present climate variability and future climate uncertainty among those who currently have less adaptive capacities to do so, i.e., female-headed households, households lacking able-bodied men aged 19-35 years, households with many dependants and households with many sick family members.

In order to implement this in practice we therefore suggest [in contrast to the national adaptation policies proposed by the governments in Tanzania and Kenya but in agreement with IFAD recommendations (2011)] a genderinformed and tri-partite integrative policy strategy with focus on: (1) financial and infrastructural support to scale up adoption of locally produced and affordable technologies and innovations; (2) education and extension services targeting and promoting a shift towards sustainable agricultural intensification; and (3) capacity building and social learning initiatives to encourage the integration of "marginalized" climate vulnerable groups into collaborative projects and collective action groups to reduce labor burdens and diversify activities and income earning
Table 4 Differences between female and male headed households in Onjiko c Out of the 22 female headed $\mathrm{HH}, 15$ are widows in the sample of a total of 50 households. Source: baseline survey of a total of 600 households conducted in September-October 2007)

\begin{tabular}{|c|c|c|c|c|}
\hline & \multicolumn{2}{|c|}{ Female $^{\mathrm{c}}$ headed HH $(n=22)$} & \multicolumn{2}{|c|}{ Male headed HH $(n=28)$} \\
\hline & (a) & (b) & (a) & (b) \\
\hline Median size of household & 4 & & 6 & \\
\hline \multicolumn{5}{|l|}{ Food sufficiency (months/year) } \\
\hline $\begin{array}{ll}\text { (a) } 10-12 \text { months } & \text { (b) } 1-3 \text { months }\end{array}$ & 9 & 2 & 10 & 4 \\
\hline \multicolumn{5}{|l|}{ Animal protein consumed (days/week) } \\
\hline $\begin{array}{ll}\text { (a) 1-3 days } & \text { (b) every day }\end{array}$ & 14 & 0 & 21 & 2 \\
\hline \multicolumn{5}{|l|}{ Land size (acres/HH) } \\
\hline (b) 1-3 acres & 12 & 8 & 8 & 17 \\
\hline \multicolumn{5}{|l|}{ Reliance on remittances } \\
\hline $\begin{array}{ll}\text { (a) very important } & \text { (b) no importance }\end{array}$ & 11 & 8 & 3 & 18 \\
\hline Mobile phone ownership & 6 & & 15 & \\
\hline
\end{tabular}


possibilities. In so doing, three important livelihood domains may be promoted and developed: the capability to farm collectively; the means to increase household buffers; and the empowerment of individual agency to enable planning for the uncertainties ahead.

Acknowledgments The authors would like to thank the Swedish International Development and Cooperation Agency (Sida) for financial support of the research project and three anonymous reviewers for insightful comments on the article. We also wish to thank all the participating stakeholders in the Kisumu workshop and SCC-VI Kisumu for arranging and co-hosting the event. Finally, our gratitude goes to the farmers who engaged so willingly in the participatory exercises. Without you this research would not have been possible.

Open Access This article is distributed under the terms of the Creative Commons Attribution License which permits any use, distribution, and reproduction in any medium, provided the original author(s) and the source are credited.

\section{References}

Adger WN (2003) Social capital, collective action, and adaptation to climate change. Econ Geogr 79(4):387-404

Adger WN (2006) Vulnerability. Global Environ Change 16(3):268281

Andersson E, Gabrielsson S (2012) Because of poverty we had to come together-collective action as a pathway to improved food security in rural Kenya and Uganda. J Int Agric Sustain 10(3): 245-262

Barrett CB (2008) Poverty traps and resource dynamics in smallholder agrarian systems. In: Dellink RB and Ruijs A (eds) Economics of poverty, environment and natural-resource use. Springer, Dordrecht

Barron J, Rockström J, Gichuki F, Hatibu N (2003) Dry spell analysis and maize yields for two semi-arid locations in east africa. Agric For Meteorol 117(1-2):23-37

Bebbington A (1999) Capitals and capabilities: a framework for analyzing peasant viability, rural livelihoods and poverty. World Dev 27(12):2021-2044

Brooks N (2003) Vulnerability, risk and adaptation: a conceptual framework. Tyndall Centre Working Paper 38, Tyndall Centre for Climate Change Research, Norwich, UK

Bryceson D (2002) Multiplex livelihoods in rural Africa: recasting the terms and conditions of gainful employment. J Mod Afr Stud 40(1): $1-28$

Clark WC (2007) Sustainability science: a room of its own. Proc Natl Acad Sci USA 104(6):1737

Cleaver F (2005) The inequality of social capital and reproduction of chronic poverty. World Dev 33(6):893-906

Cutter SL, Boruff BJ, Shirley L (2003) Social vulnerability to environmental hazards. Soc Sci Q 84(2):242-261

Dasgupta P (1997) Nutritional status, the capacity for work, and poverty traps. J Econ 77(1):5-37

Demetriades J, Esplen E (2008) The gender dimensions of poverty and climate change adaptation. IDS Bulletin 39:24-31. doi: 10.1111/j.1759-5436.2008.tb00473.x

Denton F (2002) Climate change vulnerability, impacts, and adaptation: why does gender matter? Gender Dev 10(2)

Devereux S, Edwards J (2004) Climate change and food security. IDS Bull 35:22-30
Dreze J, Sen A (1991) Hunger and public action. Oxford University Press, UK

Ellis F, Freeman HA (eds) (2005) Rural livelihoods and poverty reduction policies. London, Routledge

Enarson E (2000) Gender and natural disasters. IPCRR Working Paper No.1. International Labour Organization (September 2000)

Eriksen SH, Brown K, Kelly PM (2005) The dynamics of vulnerability: locating coping strategies in Kenya and Tanzania. Geogr J 171(4):287-305

Food and Agricultural Organization (2006) Gender the missing component of the response to climate change, Lambrou, Yianna and Grazia Piana, Gender and Population Division, Rome

Fuggle RF (2002) Lake Victoria: a case study of complex interrelationships, UNEP, 2002

Füssel HM, Klein RJT (2006) Climate change vulnerability assessments: an evolution of conceptual thinking. Clim Change 75(3):301-329

Gabrielsson S (2007) Baseline household survey. Lund University Centre for Sustainability Studies, Sweden

Gabrielsson S, Ramasar V (2012) Widows: agents of change in a climate of water uncertainty. J Cleaner Prod Special Edition: Water, Women, Wisdom, Wealth. doi: 10.1016/j.jclepro.2012.01

Githeko AK (2009) Malaria and climate change, Commonwealth Health Ministers' Update. Kenya, Nairobi

Government of Kenya (2010) National Climate Change Response Strategy, Ministry of Environment and Mineral Resources, $120 \mathrm{pp}$

Gunga S (2009) The politics of widowhood and re-marriage among the Luo of Kenya. Thought Pract J Philos Assoc Kenya 1(1):161-174

Hinkel J (2011) Indicators of vulnerability and adaptive capacity: towards a clarification of the science-policy interface. Global Environ Outlook 21(1):198-208

Hutchinson CF (1998) Social science and remote sensing in famine early warning. In: Liverman D, Moran EF, Rindfuss RR, Stern PC, Committee on the Human Dimensions of Global Change, National Research Council (eds) People and pixels: linking remote sensing and social science. National Academy Press, Washington

Ingram J, Ericksen P, Liverman D (eds) (2010) Food security and global environmental change. Earthscan, London

International Fund for Agricultural Development (2011) New realities, new challenges: new opportunities for tomorrow's generation, Rural Poverty Report 2011, IFAD, Rome

International Lake Environment Committee (2005) Managing Lakes and their basins for sustainable use-a report for Lake Basin managers and stakeholders. ILEC, Kusatsu

Ionescu C, Klein RJT, Hinkel J, Kavi Kumar KS, Klein R (2009) Towards a formal framework of vulnerability to climate change. Environ Model Assess 14(1):1-16

Kasperson JX, Kasperson RE (2001) Global environmental risk. United Nations University Press, Tokyo

Kennedy G, Nantel G, Shetty P (eds) (2003) The scourge of "hidden hunger": global dimensions of micronutrient deficiencies. Food and Agricultural Organization. FAO, Rome

Kizza M, Rodhe A et al (2009) Temporal rainfall variability in the Lake Victoria Basin in East Africa during the twentieth century. Theoret Appl Climatol 98(1):119-135

Masika R (ed) (2002) Gender and climate change. Focus on Gender, Oxfam

McCarthy JJ, Canziani OF, Leary NA, Dokken DJ, White KS (eds) (2001) Climate change 2001: impacts, adaptation and vulnerability. Cambridge University Press, Cambridge

McHugh MJ (2006) Impact of south pacific circulation variability on East African rainfall. Int J Climatol 26:505-521

Miles C (2007) Because women are property: issues of gender, food security, property ownership, quasi-development and religion in 
sub-Saharan Africa' UNU-WIDER conference on gender and food security, May 2007, Accra, Ghana

Minot N (2010) 'Summary report' COMESA Policy seminar on variation in staple food prices: causes, consequence, and policy options, Maputo, Mozambique, 25-26 January 2010. IFPRI, Washington

Misselhorn AA (2004) What drives food insecurity in Southern Africa? A meta-analysis of household economy studies. Global Environ Change 15:33-43

Morton JF (2007) The impact of climate change on smallholder and subsistence agriculture. Proc Natl Acad Sci USA 104(50): 19680-19685

Moser CON (1998) The asset vulnerability framework: reassessing urban poverty reduction strategies. World Dev 26(1):1-19

Ngombalu JK (2011) Implication of EAC member states budgets 2011/2012 on the Grain Sub-Sector, Easter African Grain Council, June 2011, Nairobi, Kenya

O‘Brien K, Eriksen S, Nygaard LP, Schjolden A (2007) Why different interpretations of vulnerability matter in climate change discourses. Climate policy 7(1):73-88

Odada EO, Ochola WO, Olago DO (2009) Drivers of ecosystem change and their impacts on human well-being in Lake Victoria basin. Afr J Ecol 47:46-54

Ogallo LA (1997) Validity of the ENSO-related impacts in eastern and southern Africa. Int J Afr Stud 2 (March), http://www.brad. ac.uk/research/ijas/ijasno2/ogallo.html.

Okuro SO (2008) Struggling with inlaws and corruption in Kombewa Division, Kenya. In: Englert B, Daley B (eds) Women's land rights and privatization in eastern Africa. Vienna Institute for International Dialogue and Cooperation, Vienna

Olago D, Marshall M et al (2007) Climatic, socio-economic, and health factors affecting human vulnerability to cholera in the Lake Victoria basin, East Africa. Ambio 36(4):350-358

Paavola J (2008) Livelihoods, vulnerability and adaptation to climate change in Morogoro, Tanzania. Environ Sci Policy 11(7):642-654

Patt AG, Schröter D, Klein RJT, de la Vega-Leinert AC (eds) (2009) Assessing vulnerability to global environmental change-making research useful for adaptation decision making and policy. Earthscan, London

Polsky C, Neff R, Yarnal B (2007) Building comparable global change vulnerability assessments: the vulnerability scoping diagram. Global Environ Change 17(3-4):472-485

Preston B, Yuen E, Westaway M (2011) Putting vulnerability to climate change on the map: a review of approaches, benefits, and risks. Sustain Sci 6(2):177-202

Pretty J, Toulmin C, Williams S (2011) Sustainable intensification in African agriculture. J Int Agric Sustain 9(1):5-24

Ragin C, Amoroso L (2011) Constructing social research: the unity and diversity of method, 2nd edn. Pine Forge, Newbury Park, CA

Ribot JC, Magalhaes A, Panagides S (eds) (1996) Climate variability, climate change, and social vulnerability in the semi-arid tropics. Cambridge University Press, Cambridge

Rosenzweig C, Iglesias A, Yang X, Epstein P, Chivian E (2001) Climate change and extreme weather events: implications for food production, plant diseases, and pests. Global Change Human Health 2:90-104
Schröter D, Polsky C, Patt A (2005) Assessing vulnerabilities to the effects of global change: an eight step approach. Mitig Adapt Strat Glob Change 10(4):573-595

Scoones I (1998) Sustainable rural livelihoods: a framework for analysis. IDS, UK

Scoones I, Thompson J (eds) (2009) Farmer first revisited: innovation for agricultural research and development. Practical Action, Rugby

Sen A (1999) Commodities and capabilities. Oxford University Press, UK

Slegers MFW, Stroosnijder L (2008) Beyond the desertification narrative: an agricultural drought framework for semi-arid East Africa. Ambio 37(5)

Smit B, Pilifosova O (2003) From adaptation to adaptive capacity and vulnerability reduction. In: Smith JB, Klein RJT, Huq S (eds) Climate change, adaptive capacity and development. Imperial College Press, London

Smucker TA, Wisner B (2008) Changing household responses to drought in Tharaka, Kenya: vulnerability, persistence and challenge. ODI/Blackwell Publishing, Oxford

Swallow BM, Sang JK et al (2009) Tradeoffs, synergies and traps among ecosystem services in the Lake Victoria basin of East Africa. Environ Sci Policy 12(4):504-519

Thompson J, Scoones I (2009) Addressing the dynamics of agri-food systems: an emerging agenda for social science research. Environ Sci Policy 12(4)

Thornton PK et al (2010) Adapting to climate change: agricultural system and household impacts in East Africa. Agric Syst 103:73-82

Traerup SLM, Mertz O (2011) Rainfall variability and household coping strategies in northern Tanzania: a motivation for districtlevel strategies. Reg Environ Change 11(3):471-481

Turner BL, Kasperson RE, Matson PA, McCarthy JJ, Corell RW, Christensen L, Eckley N, Kasperson JX, Luers A, Martello ML, Polsky C, Pulsipher A, Schiller A (2003) A framework for vulnerability analysis in sustainability science. Proc Natl Acad Sci USA 100:8074-8079

United Nations Environment Program (2006) Odada E, Olago D, Ochola W (eds) Environment for development: an ecosystems assessment of Lake Victoria basin environmental and socioeconomic status, trends and human vulnerabilities. UNEP/PASS, Nairobi, Kenya

United Republic of Tanzania (2007) National Adaptation Program of Action (NAPA), Division of Environment, $52 \mathrm{pp}$

Wandiga S (ed) (2006) Climate change induced vulnerability to malaria and cholera in the Lake Victoria Region-a final report. Assessments of impacts and adaptations to climate change project. The International START Secretariat, Washington, DC, USA

Watts MJ, Bohle HG (1993) 'The space of vulnerability: the causal structure of hunger and famine' in. Prog Hum Geogr 17(1):43-67

Wisner B, Luce HR (1993) Disaster vulnerability: scale, power and daily life. GeoJournal 30(2):127-140

World Bank (2008) Agriculture for Development, World Development Report 2008, World Bank, Washington, DC

Yohe G, Tol R (2002) Indicators for social and economic coping capacity-moving toward a working definition of adaptive capacity. Global Environ Change 12:25-40 